\title{
Twin Anemia-polycythemia Sequence
}

Nivetha Gunasekar

\begin{abstract}
Twin anemia-polycythemia sequence (TAPS) is characterized by a massive difference in red blood cells between two monochorionic (MC) embryos despite indication of a syndrome of twin oligo-polyhydramnios. ${ }^{1}$ A nulliparous woman has an MC twin diamniotic switched for premature labor. ${ }^{2}$ Keywords: Anastomoses, Monochorionic twin, Polycythemia.

Pondicherry Journal of Nursing (2021): 10.5005/jp-journals-10084-12162
\end{abstract}

\section{INTRODUCTION}

Twin anemia-polycythemia sequence (TAPS) is a syndrome occurs in monochorionic (MC) twins of fetofetal transfusion, resulting in chronic intertwined transfusion of blood via the small anastomoses of placenta give on to substantial variations in red blood cells between donor and recipient, with no manifestations of deficit liquor and more amount of liquor twin. This condition spontaneously arise in $2-5 \%$ of MC pregnant women and develation. $^{3}$

\section{What is Twin Anemia-polycythemia Sequence?}

Twin anemia-polycythemia sequence is an abnormal chronic form of sibling-twin transfusion syndrome (TTTS) induced by the delayed transfusion of hemoglobin via some few very small placental arteriovenous anastomoses ( $<1 \mathrm{~mm}$ in diameter), leading in iron deficiency of one twin and co-twin polycythemia. ${ }^{4}$ Amounts of amniotic fluid are standard. The cardinal maternal analysis is the location of MC with a main cerebral artery-systolic velocity $>1.5$ multiples of mean (MoM) in the first twin and $<0.8$ MoM in the second twin (Fig. 1). ${ }^{5}$

\section{Prevelance}

- Spontaneous: $5 \%$ of MC twins. It normally occurs $>26$ weeks of gestation.

- Placental vessels after laser ablation: $2-10 \%$ of MC twins. ${ }^{6}$

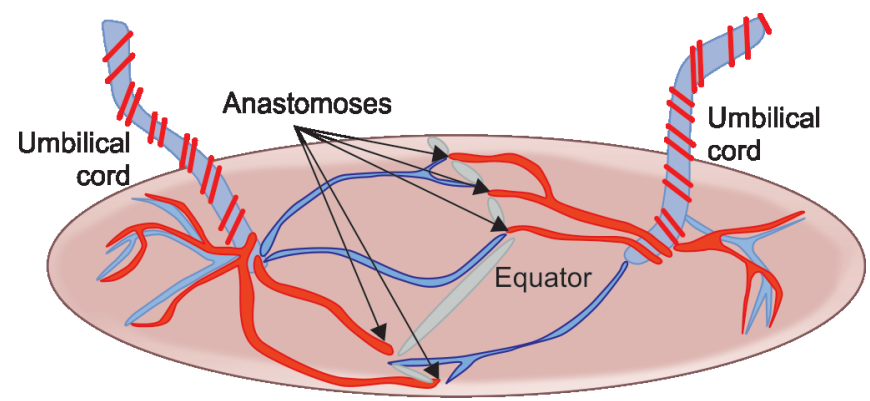

Fig. 1: Connection of tiny peripheral artery to vein
Department of Obstetrics and Gynecology Nursing, Kasturba Gandhi Nursing College, Puducherry, India

Corresponding Author: Nivetha Gunasekar, Department of Obstetrics and Gynecology Nursing, Kasturba Gandhi Nursing College, Puducherry, India, Phone: +91 8870619642, e-mail: ammunive83@gmail.com

How to cite this article: Gunasekar N. Twin Anemia-polycythemia Sequence. Pon J Nurs 2021;14(1):21-22.

Source of support: Nil

Conflict of interest: None

\section{SYMPTOMS OF TAPS}

- Low red blood count (anemia) in the twin donor and thicker than normal blood count (polycythemia) in the twin recipient. ${ }^{7}$

- The recipient twin may have a slow flow of blood in small vessels.

- Suffer from spontaneous obstruction of blood flow (thrombosis). ${ }^{8}$

\section{Diagnosis and Staging}

Accurate ultrasonography (USG) exam, including electrocardiography (ECG) (to evaluate cardiac function) and evaluation of middle cerebral artery-peak systolic velocity (MCA-PSV) (to anticipate anemia and polycythemia levels).

\section{TAPS Antenatal Classification}

- Stage 1: Delta MCA-PSV >0.5 MoM (absence of fetal compromise).

- Stage 2: Delta MCA-PSV>0.7 MoM (without fetal compromise).

- Stage 3: First or second stage, with compromise of cardiac donor.

- Stage 4: Hydrops of donor.

- Stage 5: Single or both fetuses can be death preceded by TAPS. ${ }^{9}$

Postnatal TAPS Classification by Intertwined Red Blood Cell Differences

First stage: $>8.0 \mathrm{~g} / \mathrm{dL}$. Second stage: $>11.0 \mathrm{~g} / \mathrm{dL}$. Third stage: $>14.0 \mathrm{~g} / \mathrm{dL}$. Fourth stage: $>17.0 \mathrm{~g} / \mathrm{dL}$. Fifth stage: $>20.0 \mathrm{~g} / \mathrm{dL}^{10}$

(0) The Author(s). 2021 Open Access This article is distributed under the terms of the Creative Commons Attribution 4.0 International License (https:// creativecommons.org/licenses/by-nc/4.0/), which permits unrestricted use, distribution, and non-commercial reproduction in any medium, provided you give appropriate credit to the original author(s) and the source, provide a link to the Creative Commons license, and indicate if changes were made. The Creative Commons Public Domain Dedication waiver (http://creativecommons.org/publicdomain/zero/1.0/) applies to the data made available in this article, unless otherwise stated. 


\section{MANAGEMENT}

\section{Less than 26 Weeks of Gestation}

Laser ablation can be performed through fetoscope of communicative placental vessels. Subsequently, each 1 week, fetal growth, anatomy of the brain, and MCA-PSV will be monitored. At $\geq 32$ weeks of gestation, magnetic resonance imaging (MRI) should be taken to diagnose the disorder of neuronal migration. If the babies are functionally normal, the delivery of the baby by spontaneous vaginal delivery can take place at 37 weeks of gestation.

\section{6-30 Weeks of Gestation}

Transfusions of blood to the anemic twin and exchange transfusions to the polycythemic twin solution of Hartmann's. Every 2-3 days Doppler assessment, every 3-4 days procedure may become necessary.

\section{More than 30 Weeks \\ Delivery can be cesarean section. ${ }^{11}$}

\section{Prognosis}

Neurodevelopment can be delayed up to $20 \%$ of cases, which depends on the age at birth of baby. The probability is greater for the twin receiver.

\section{Recurrence}

There is no more risk of relapse. ${ }^{12}$

\section{Conclusion}

TAPS is a new abnormal form of TTTS that provides a huge intertwined red blood cell variation with one twin making low red blood cells and trying to develop polycythemia without the oligohydramnios-polyhydramnios series necessary to identify TTTS. ${ }^{8}$

\section{References}

1. Tollenaar LSA, Lopriore E, Middeldorp JM, Haak MC, Klumper FJ, Oepkes D, et al. Improved prediction of twin anemia-polycythemia sequence by delta middle cerebral artery peak systolic velocity: new antenatal classification system. Ultrasound Obstet Gynecol 2019;53(6):788-793. DOI: 10.1002/uog.20096.

2. https://fetalmedicine.org/education/fetal-abnormalities/multiplepregnancies/mc-twins-death-of-one-fetus.

3. Twin Anemia Polycythemia Sequence (TAPS) | Pavilion for Women. https://women.texaschildrens.org/program/texas-childrens-fetalcenter/conditions-we-treat/twin-anemia-polycythemia-sequencetaps.

4. Slaghekke F, van den Wijngaard JPHM, Akkermans J, van Gemert MJC, Middeldorp JM, Klumper FJ, et al. Intrauterine transfusion combined with partial exchange transfusion for twin anemia polycythemia sequence: modeling a novel technique. Placenta 2015;36(5):599-602. DOI: 10.1016/j.placenta.2015.01.194.

5. Nicholas LD, Fischbein RL, Bhamidipalli SS. Twin anemiapolycythemia sequence and routine monitoring practices amongst maternal-fetal medicine specialists in the United States: an initial investigation. J Perinat Med 2019;47(4):388-392. DOI: 10.1515/jpm2018-0240.

6. Sananès N, Veujoz M, Severac F, Barthoulot M, Meyer N, Weingertner $A S$, et al. Evaluation of the utility of in utero treatment of twin anemiapolycythemia sequence. Fetal Diagn Ther 2015;38(3):170-178. DOI: 10.1159/000380822, www.karger.com.

7. Gucciardo L, Lewi L, Vaast P, Debska M, De Catte L, Van Mieghem T, et al. Twin anemia polycythemia sequence from a prenatal perspective. Prenat Diagn 2010;30(5):438-442. DOI: 10.1002/pd.2491.

8. Tollenaar LSA, Slaghekke F, van Klink JMM, Groene SG, Middeldorp $J M$, Haak MC, et al. Twin-twin transfusion syndrome with anemiapolycythemia: prevalence, characteristics, and outcome. J Clin Med 2019;8(8). DOI: 10.3390/jcm8081129.

9. Fratelli N, Prefumo F, Zambolo C, Zanardini C, Fichera A, Frusca T. Conservative management in a case of iatrogenic twin anemiapolycythemia sequence. Ultrasound Obstet Gynecol 2012;39(5):597598. DOI: 10.1002/uog.10135.

10. https://www.hopkinsmedicine.org/health/conditions-and-diseases/ twin-anemia-polycythemia-sequence-taps.

11. Slaghekke F, Zhao DP, Middeldorp JM, Klumper FJ, Haak MC, Oepkes $D$, et al. Antenatal management of twin-twin transfusion syndrome and twin anemia-polycythemia sequence. Expert Rev Hematol 2016;9(8):815-820. DOI: 10.1080/17474086.2016. 1200968.

12. Slaghekke F, Pasman S, Veujoz M, Middeldorp JM, Lewi L, Devlieger $\mathrm{R}$, et al. Middle cerebral artery peak systolic velocity to predict fetal hemoglobin levels in twin anemia-polycythemia sequence. Ultrasound Obstet Gynecol 2015;46(4):432-436. DOI: 10.1002/ uog. 14925. 